\title{
The Effectiveness of Inquiry Jurisprudential Development Model in Civics Learning Process at SMA Negeri 1 Kawangkoan Minahasa
}

\author{
Telly Delly Wua* \\ Pancasila and Civic Education \\ Department \\ Faculty of Social Sciences, \\ Universitas Negeri Manado \\ Tondano, North Sulawesi, Indonesia \\ TellyWua@unima.ac.id
}

\author{
Julien Biringan \\ Pancasila and Civic Education \\ Department \\ Faculty of Social Sciences, \\ Universitas Negeri Manado \\ Tondano, North Sulawesi, Indonesia \\ julienbiringan@unima.ac.id
}

\author{
Mardan Umar \\ Pancasila and Civic Education \\ Department \\ Faculty of Social Sciences, \\ Universitas Negeri Manado \\ Tondano, North Sulawesi, Indonesia \\ mardanumar@unima.ac.id
}

\begin{abstract}
This is a research development aimed to get a description of the effectiveness of the application of the Jurisprudential Inquiry model and to find out the various obstacles on its application for Civics learning in SMA 1 Kawangkoan. The used method is a classroom action research and data collection techniques are observation and documentation relating to the problem related to the study. The results show teaching and learning activities on Civics subject matter need to be developed by implementing innovative and effective models such as Jurisprudential Inquiry, and other relevant models. The application of the Jurisprudential Inquiry model, which was developed through three aspects, namely the scope of the problem, the attitude of the students and the aspects of the implementation of the assessment, was significantly effective and could improve the evaluation of the process of teaching civics rationally students felt there was satisfaction with the assumptions proposed.
\end{abstract}

Keywords: Effectiveness, Jurisprudential, Inquiry, Learning, Civics

\section{INTRODUCTION}

Citizenship Education has its own characteristics that are different from other subjects. The difference caused by the characteristic of Civics Education is value education or moral education. As values education, context and changes occurred in the strategic environment of schools, bring changes in the Civics paradigm. Nowadays the new paradigm of Civics is directed at the formation of citizens who have intelligence (civic intelligence), citizens who are responsible (civic responsibility), and citizens who are participative (civic participation) in solving common problems and our efforts to build a democratic shared life. This is in line with the opinion of Juliardi Budi[1], where citizenship education seeks to shape learners with participatory skills empower them to respond and solve problems in society in a democratic manner.

In this connection, the new paradigm will be a very serious challenge for schools, especially teachers, as Sapriya[2] said teachers have positions as well as respectable professions and should be role models for students as competencies to make good citizens. However, the empirical facts observed weaknesses both in terms of developing learning objectives, teaching materials, learning strategies, and in the evaluation system. The weaknesses in the strategic elements turned out to be very influential in student learning outcomes themselves.

The problem of the low quality of education or the quality of student learning outcomes has become one of the national problems in addition to the problem of educational efficiency, the issue of educational equity, and the problem of educational relevance. These problems many efforts have been made to reform both systemic and instrumental. Instrumental reformation is often done is reforming and improving the quality of the learning process. In this connection, efforts have been made to adopt learning innovations such as student active learning, process skills, inquiry methods, problem-solving methods, and other innovations. As stated by Ismail [3], efforts to improve the quality of education can be done by improving the overall quality by empowering available educational resources.

The development and implementation of various innovations in the learning process require comprehensive efforts in the sense of being based on the results of studies both theoretical and empirical studies. It means the process of forming competencies requires a precondition that should be conducive to the implementation of quality learning through a quality competency process that is expected to be formed. The precondition is mainly related to the ability of teachers to identify the competency characteristics of each subject including the characteristics of Civics subjects, which can be developed through a learning process for competencies can be formed.

However, the difficulty faced is when the demands of the 2013 curriculum contextuality require the competencies should be identified, compiled, formulated, and developed by each teacher according to the conditions of each region and each school. Likewise, instrumental factors such as learning facilities for the needs of learning media are not adequately available will become obstacles for the process of forming competencies. These factors lead to needing the ability of teachers to develop innovative learning models, 
to the process of forming competencies becomes more effective.

As an innovation, the inquiry jurisprudential learning model has not been so widely applied by Civics teachers, comprehensively expected goals are not achieved, and It is necessary to develop the Jurisprudential Inquiry model optimally.

\section{METHOD}

This is research development in the form of Classroom Action Research (CAR), Bruce Joyce's model[4], Implementation was conducted in SMA N. 1 Kawangkoan Minahasa. This school was chosen based on the criteria set by the Department of Education which have implemented the 2013 curriculum, available civics teachers who have the educational background and teaching experience in the civics field of study.

The research framework for both center and PTK research is described as follows: 1) Identification of the characteristics of the jurisprudence inquiry model of Civics teaching, 2) Estimated implementation time, 3) Analysis of supporting resources; and 4) Face-to-face, observation and reflection on planning, instructional effects, process skills, and the feasibility of objective conditions. Observation uses an observation sheet, and at the same time as an instrument for data collection. The observed aspects are the achievement of competencies as seen in the indicators of each competency, namely: 1) Involvement in the planning process; 2) mastery of aspects of the Jurisprudential Inquiry learning model ; 3 ) the ability to analyze and formulate: objectives, steps, material, and assessment of learning outcomes; 4) case orientation, problem identification; 5) positioning, Examples, and arguments, Mastery of social issues frameworks; 6) The ability to identify problems, the ability to present problems, the ability to analyze and appoint the consequences of the problem discussed; 7) learning outcomes; 8) availability of learning facilities; 9) the state of the teacher; and 10). support system.

The steps for conducting research include planning, action, and observation. Then this research framework is built from the rationale of learning values in Civics. To strengthen the value in Civics, the 2013 curriculum was developed. Through the curriculum developed a number of competencies. This research is focused on developing jurisprudential inquiry learning models according to syntax, namely:

Data analysis was conducted descriptively in units of percentage calculations for the achievement of the observed indicators.

\section{RESULTS AND DISCUSSION}

\section{A. Research Result}

\section{Description of Research Implementation}

This research is a development study using Donald Ary's model, Lucy Cheser [5], in which the development of learning models implemented by teams and Civics subject teachers. The realization of this research activity is each team has a role that can be described as follows: The research team with the teacher's role: Identifying the characteristics of the Jurisprudential Inquiry learning model in Civics learning process; Determine the estimated time of implementation; Conduct guidance/tutorial on the implementation of teaching and learning activities; make observations; Conducting reflection and analysis of instructional effects, the accompanying effect of the achievement of competencies with the jurisprudential inquiry model; Conducting analysis of supporting resources for the implementation of research;

Identifying the characteristics of Jurisprudential Inquiry learning in three aspects namely aspects of student attitudes, the scope of the problem and the effectiveness of the assessment; Implement/realize teaching and learning activities using teaching methods are relevant from the three aspects observed; Make observations by recording data; Conducting reflection and analysis of learning process skills by applying the three aspects of Jurisprudential Inquiry learning: Identifying the characteristics of each learning model by conducting teaching and learning activities oriented towards learning preparation by applying the Jurisprudential Inquiry model; Conduct observations of the implementation of teaching and learning activities; Conduct a reflection and analysis of the effects of the application of the Jurisprudential Inquiry learning model with three aspects studied namely the scope of the problem (problem area), student attitudes, and the implementation of assessment; Conduct coaching activities towards the implementation of teaching and learning activities.

The implementation of this research began by coordinating activities with the research team and the teacher team. This joint coordination is conducted in the context of the preparation of the RPP determining the implementation time, and the implementation of teaching and learning activities. Furthermore, the implementation of research whose order is in the process of teaching and learning activities is integrated with the schedule of learning activities in the classroom or at school. The implementation of teaching and learning activities in schools by applying the inquiry jurisprudential model through three aspects can be described as follows:

Development of Jurisprudential Inquiry models in Civics learning.

The research was conducted by applying the inquiry jurisprudential learning model located in SMA Negeri 1. Kawangkoan Minahasa. The students who were the focus of the study of the application of learning for the development of the inquiry jurisprudential learning model were 40th-grade students of Natural Sciences. Classroom arrangements are designed according to the interests of the classroom action research process. In this connection, the implementation of the learning process is developed and applied based on Michael's [6] model of inquiry model jurisprudential learning by taking the following steps:

\section{Step 1. Case Orientation}

The implementation of the learning process in this round and the first step is the teacher's role in the opening lesson and providing general deliverables connected the activities to be realized. In this step the core activities of teachers in the learning process are (1) identifying or introducing a problem according to the ideal targets, values and subject matter, (2) Generating student enthusiasm by expressing a case being discussed to be explicit, and (3) 
Interpreting the history of the problem by investigating issues. The role of the teacher is trying to arouse the enthusiasm of student learning so that students discover the value of the subject. In this situation, the teacher can directly pay attention to the reaction of students, in this case, are students. Furthermore, the role of students is to pay attention and listen to the explanation delivered by the teacher and find and choose cases.

At this meeting the material presented was according to the subject for class XI, namely the subject of "Selfpotential". The teacher conveyed the organization in general about the orientation of public cases' respect to the material for self-potential.

Observations made by taking its components namely problem identification and analysis, interview guidelines, attitude scale which is equipped with a number of instruments related to the learning model applied that can demonstrate the achievement of the problem coverage aspects of students. Continuation of observations conducted by using the format of observation and evaluation of individual students, including aspects of the significance of the problem raised, understanding of the problem, argumentation, response, and an attitude of respect for the opinions of others.

\section{Step 2: Identify the Problem}

Implementation of learning activities in this step is the teacher's role in conveying subject matter is continued by proposing various examples of problems. Students in this step are finding and identifying cases/problems connected to the material being taught. After the problem is identified, the teacher brainstorms the proposed problems and then prioritizes one of the problems to become the main study material.

\section{Step 3: Positioning}

The realization of this step is to determine the main problems that have been identified and the determination of the position of the problem in relation to various public problems are related to the subject matter. Then students in this step are expected to be able to connect facts and cases, formulate a problem, and identify value conflicts. Teaching and learning activities can be realized by forming small groups with the following activities: (1) Division of groups, each group consisting of 3-4 students, (2) Each task group completes a case orientation with respect to disciplinary attitude, asking, and make a discussion report as a class report. Each group member is responsible for the assessment responses given. Group cohesiveness completes all responses and provides responses and reports on the comments of other groups. Finally, make a report on the results of group discussion and present it to ask other groups for their responses to give an assessment

\section{Step 4: Give Examples and Arguments}

In this step, the teacher presents an outline of the subject matter accompanied by case examples. Students pay attention to the teacher's delivery and analyze it according to the examples presented, followed by giving an argument based on the problem discussed, selected/identified. The teaching and learning process takes place in the form of groups as in step three above.

\section{Step 5: Position Testing}

In this step, the activity is implemented to begin testing the position of the cases discussed. The teacher in this step still gives an explanation of the material in general by using varied lecture methods. Then students pay attention to the teacher's explanation and ask what they feel is not understood to be clarified by the teacher. After the material is presented by linking the position of the case discussed, then at the end of this step the teacher conducts a test of the position of the case which is related to the material presented.

\section{Step 6: Testing the assumptions}

Based on the assumptions put forward in the steps above, the implementation of activities in this round is (conducting a test of the assumptions, by 1) conducting a review of the group material presentation regarding events, positions and realism, (2) conduct main focus discussions, (3) develop assumptions, (4) test assumptions, and (5) conduct process evaluations.

\section{Impact of Learning}

The impact of learning, especially instructional and accompaniment impacts are reflected in the achievement of indicators as follows (1) changes in attitudes in terms of learning, (2) being critical in accepting something, (3) Increasing the ability to give arguments, (4) there are changes in addressing and assessing the meaning of life, (5) increasing the ability to organize values in learning, (2) increasing student learning activity initiatives, (2) increasing independent and group learning efforts, and changes in learning habits.

\section{B. Discussion of Research Results}

The research findings described can be explained by several important things as follows:

Characteristics of Inquiry Jurisprudence Competency

Citizenship Education (PKn) as stated by Yahya and Machfiroh[7] which is curricular designed as a subject of learning aims to develop the potential of individuals to become Indonesian citizens who are noble, intelligent, participatory and responsible. It is clear in order to achieve the above objectives, the teacher needs to apply an innovative model such as Jurisprudential Inquiry, due to characteristics of Jurisprudential Inquiry learning are competencies and capacities be formed through the three aspects namely ability to include problems, ability to take the attitude, ability to conduct and give an assessment.

Research findings show inquiry jurisprudential learning competencies can be shaped through various approaches or learning models. The level of competency achievement is expected to be formed through learning all three aspects turned very well with an achievement level above $85 \%$. This achievement indicates several important things, namely: (1) That the inquiry jurisprudential learning model through the assessment the scope of the problem, student attitudes and aspects of the implementation of assessment, can be developed and implemented in schools; (2) Learning models such as inquiry jurisprudential have a very good impact on the formation of competencies comprehensively. 
Theoretically, this is possible due to orientation and emphasis each of these aspects is active student learning.

Students are given learning experiences to be able to identify case sources that have implications for teaching morality and norms. Then students can find a choice of values according to the problem areas, have confidence in classifying and clarifying a case contains a number of values, have a commitment in determining attitudes, have high self-awareness in accepting grades, students are more critical in accepting and analyzing cases, students have broad insights in solving various problems invite to be in alternative solutions, students have the ability to provide arguments in determining a case being discussed, students can demonstrate the ability to consequently determine the assessment; (3) Competence in learning formed values, provides opportunities to the achievement of educational level curriculum objectives which in essence provide opportunities for the achievement of student competencies. It means contained in the value learning competency provides opportunities for students in various subjects to be able to exist in studying and analyzing and clarifying various problems and orientation and consequences of their assessment; and (4) Inquiry jurisprudential learning through assessment of aspects scope of the problem, student attitudes and implementation of assessments has competencies not only have an impact on Civics learning but also in the learning process in other subjects.

Instructional Impact

The inquiry jurisprudential learning model through the assessment of three aspects was developed to provide a fairly good instructional effect and accompaniment effect on most students $>85 \%$ of students. The result of the study showed the instructional impact and the accompanying impact of each of the aspects studied was very significant. It means each aspect of inquiry jurisprudential learning through assessment the scope of the problem, student attitudes, and the implementation of the assessment can effectively have a significant impact on the formation of implicit competencies it can create the conditions of teaching and learning expected in Civics learning, where students achieve competence in analyzing various problems arise in the community as a Civics laboratory. This is in line with the opinion of Komalasari [8] one of the main goals of moral education is to help students to help the ability to think logically and scientific findings in analyzing social problems related to certain moral values. Research Findings

Based on the analysis, there are some important things which are the findings in this study to be discussed, namely: (1) Innovative learning process-oriented to active student learning, will have a significant impact on the formation of competencies. Implications for jurisprudential learning through the assessment of three aspects can have a significant impact in strengthening the achievement of competencies comprehensively; (2) Through the results of this study can provide a strong justification for the importance of the efforts of teachers in developing innovative learning processes, studentcentered learning, and learning provides opportunities and wider learning experiences for students. This means empirical observations have stated the weaknesses of the learning process, namely the directive learning process is a weak point causes the low quality of the learning process and the low value of student learning outcomes; (3) The importance for teachers to develop or provide broader learning experiences for students, to be more real. Due to such learning experiences will strengthen the commitment competencies should be formed through learning experiences, namely giving experiences to students to experience and do themselves through such learning processes and experiences that competencies can be formed; (4) The findings of this study indicate it is very important for teachers to avoid the learning process by giving assignments to memorize as many students do. Abilities, skills, and attitudes and values cannot be formed through directive learning experiences but, only be formed through real learning experiences.

According to the formation of competence implicit, it is the formation of the affective domain, the teacher can apply an innovative model, more over, the pursuit of orientation is the teaching of values, morals, and norms. As Umar [9] said that aspects of knowledge, attitude and social skills must be priority to strengthening the national character. Therefore, the inquiry jurisprudential learning model is an alternative for the purpose of teaching Civics and should be applied by teachers who conduct teaching and learning activities on these subjects.

Analysis of competency achievement through the model of inquiry jurisprudential in Civics Learning.

The formation of competencies through the application of inquiry jurisprudential learning models shows the comprehensive achievement of Competencies is the cognitive domain, affective domain, and psychomotor as an implementation of process skills. These aspects can be seen through the achievement of the existing conferences in learning values. Analysis of the inquiry jurisprudential model includes abilities such as 1) the ability to orientate a case; 2 ) the ability to identify problems; 3 ) the ability to determine the position of a case that is a public issue; 3 ) the ability to give examples and arguments; 5) the ability to test case positions and 6) the ability to test an assumption. These abilities are realized in the Civics learning process in SMA N. 1 Kawangkoan Minahasa, its indicators that students realize learning is a necessity, students as efficiently and as effectively as possible use time to learn without any coercion, always using the library as a means of supporting learning. At a higher level, the ability to critically evaluate the indicators of competency achievement in a comprehensive manner can be achieved, selecting them according to the needs-based on a critical assessment of the benefits and usefulness of the values obtained.

The findings study explains some important issues to be discussed. First, the problem of the comprehensiveness of the achievement of competencies in learning. An important benefit of the results of this study is the discovery of learning models comprehensively strengthen the achievement of learning objectives. Through the assessment of aspects of the scope of the problem can be strengthened students' ability to find and choose a case as material for analysis and active stimulus in an academic, 
social, and emotional interaction. Academically the ability to reason, reason, and think critically about various problems can be developed. Socially built and developed social attitudes and strong social relations through workgroups, and emotionally can be trained the ability to respect each other, understand each other, respect, and a sense of teamwork together. Likewise, through the game method, a process of forming students' personalities by enabling students to capture, explore, internalize which basically can strengthen the achievement of learning objectives. Then the assessment of aspects of student attitudes, which involve the whole learning elements emphasize the affective domain can be developed as aspects of values, morals, and norms.

Second, these findings also found fundamental problems, especially related to the curriculum implementation strategy of the education unit level. This means the application of learning models in an effort to achieve competence in inquiry jurisprudential teaching will be largely determined by the readiness of both teachers and students as well as the condition of the school environment, the principal's leadership and the support of teachers. Regarding the curriculum factor, the application of the inquiry jurisprudential model requires time, it requires the teacher's ability to design structured activities outside of face-to-face hours. In addition, the achievement of curriculum material can be overcome by developing problems in an integrated or integrated way from several subjects. By this strategy, the results of the analysis of the achievement of student competencies towards curriculum material based on the three aspects of inquiry jurisprudence show curriculum targets can be achieved because through the learning process developed students learn comprehensively and are integrated through problems or themes are topics from a subject or sub-topic contained in the outlines of the Pancasila and Citizenship $(\mathrm{PKn})$ education teaching program.

\section{CONCLUSIONS AND RECOMMENDATIONS}

\section{A. Conclusion}

Based on the research data and analysis results described, it can be concluded several important things as follows: (1) The application of the Jurisprudential Inquiry model developed through three aspects namely the scope of the problem, student attitudes and aspects of the implementation of the assessment, significantly effective and can improve evaluating the process of teaching civics, students feel rationally satisfied with the assumptions proposed; (2) The application of the Inquiry Jurisprudential learning model in teaching and learning activities in class is influenced by a number of determinant factors. These factors can be seen from the factors of teachers, learning system factors, especially the directive learning model, curriculum factors, social systems, and support systems, especially related to the availability of facilities for conducting process evaluation; (3) The development of portfolio-based valuation validation can significantly strengthen the achievement of a competency-based comprehensive evaluation; (4) Through the application of the Jurisprudential Inquiry learning model, it can measure the achievement of learning objectives quite well, there is consistency in attitude and behavior with considerations for testing assumptions and conclusions .; and (5) Implications of the application of Inquiry Jurisprudential learning model to summarize strategies for developing curriculum at the education unit level, namely supporting teachers, the social environment and other support systems. Theoretically this inquiry jurisprudential learning model can strengthen the achievement of student competencies comprehensively, it influences the expected evaluation.

\section{B. Suggestions}

Based on the discussion and conclusions, there are some suggestions can be formulated in connection with the development of the Jurisprudential Inquiry learning model. The suggestions are as follows: (1) Development and application of innovative learning models, suggests the need for preparation and readiness of teachers in schools. Some aspects need to be strengthened are the need for education and training for teachers regarding the mastery of theoretical foundations and assumptions regarding the Jurisprudential Inquiry learning model; (2) The application of the inquiry jurisprudential learning model can form a technical ability in compiling and planning and implementing the learning model, and the ability to evaluate and develop innovative steps; (3) To improve the quality of teachers be done through institutional collaboration between schools and educational institutions of educational staff or through the national education office in each region. The Subject Teachers' Conference Meeting (MGMP) as well as the dissemination of innovative assessment models; and (4) For educational institutions educational staff are needed efforts to review the curriculum of relevance for the achievement of teaching competencies as well as the achievement of comprehensive evaluation.

\section{REFERENCES}

[1] J. Budi, Pendidikan Kewarganegaraan Untuk Perguruan Tinggi. Jakarta: PT. Rajagrafindo Persada, 2014.

[2] Sapriya, Konsep Dasar Pendidikan Kewarganegaraan. Bandung: Laboratorium PKn UPI, 2017.

[3] F. Ismail, "Manajemen Berbasis Sekolah: Solusi Peningkatan Kualitas Pendidikan,” J. Pendidik. Islam Iqra', 2018.

[4] B. R. Joyce, M. Weil, and E. Calhoun, Models of Teaching, 5th Edition. 1996.

[5] C. K. S. Donald Ary, Lucy Cheser Jacobs, Asghar Razavieh, Introduction to Research in Education Eighth Edition. 2009.

[6] Michael, "Dasar-dasar Utama Praktek Belajar Kewarganegaraan," Jakarta, 2012.

[7] A. Yahya and R. Machfiroh, Civic Education di Perguruan Tinggi Indonesia. Bandung: Alfabeta, 2014.

[8] Kokom Komalasari, Pembelajaran Kontekstual, Konsep dan Aplikasi. 2013

[9] A. Supriati and M. Umar, "Optimization of the Civic Education as the Effort to Strengthen National Character in Multicultural Community," vol. 251, no. Acec, pp. 193-196, 2018. 